\title{
BUSINESS STRATEGY OF FOOTBALL CLUB IN INDONESIA: A CASE STUDY AT PT BALI BINTANG SEJAHTERA (BALI UNITED FC)
}

\author{
Putra K. Try Budi Upadana*, Gorda A.A.N. Eddy Supriyadinata \\ Undiknas Graduate School, Bali, Indonesia \\ *E-mail: danangglam@gmail.com
}

\begin{abstract}
This paper tries to find out the business strategies used by PT Bali Bintang Sejahtera (Bali United FC) and explains the reciprocity obtained by PT Bali Bintang Sejahtera (Bali United FC). This research is expected to be able to add knowledge and insight to the compiler about the importance of the benefits of business strategy practices that actually occur at the club football in Indonesia, in addition, is expected to be a reference for other researchers who conduct research with the same object so that they can develop knowledge in strategy management. The main objective of this article is to determine the company's business strategy for the football club and develop the club and reciprocal what gets by the management.
\end{abstract}

\section{KEY WORDS}

Management, business strategy, reciprocity, football club.

In recent years, the world of football has been called an industry. Its characteristics are almost similar to entertainment services or businesses, because people all over the world can choose whether to go to the cinema, to an amusement park or to a stadium to watch a match. The ranking of soccer as a business activity has experienced an increase in the economies of countries where football has been promoted as a national sport. In these countries, soccer provides a large percentage of the country's gross domestic product (GDP) because football matches also encourage a large number of other sectors, such as the media and other services, namely catering and transportation. The globalization of the football industry has triggered a concentration of resources in several big clubs countries in Europe and South America that already have the ability in economic resources to face increasing competition from foreign clubs and other businesses in the entertainment industry (Dolles, H., \& Soderman, S. (2005) Globalization of Sports - The Case of Professional Football and its International Management Challenges, German Institute for Japanese Studies, 9-10).

In Indonesia, the soccer industry began when no professional budget funds were used by professional soccer clubs. The soccer clubs that have existed in Indonesia generally are in the form of a union or union owned by the regional government. As a result of Law No. 3 of 2005 and Permendagri No. 22 of 2011, soccer clubs in Indonesia have a form of ownership of a limited company whose funding is managed by the club's management. However, over time, it turns out that soccer clubs in Indonesia still cannot be said to be professional because there are still many cases of arrears in player salaries, stadium facilities that still use local government, as well as chaotic league governance (Narazine, 2016, November, 28, 28 National Football Industry Between Dreams and Ironies Retrieved from http://narazine.co/industri-sepakbola-nasional-antara-impian-dan-ironi /).

In 2017-2018 there were several cases of arrears in salary from participating League 1 and League 2 soccer clubs handled by the Indonesian Professional Footballers Association (APPI). The Indonesian Professional Footballers Association (APPI), which aims to protect the rights of Indonesian professional footballers, has communicated with related parties, both the disputing clubs, the All Indonesian Football Association (PSSI), operators (PT Liga Indonesia Baru), and also the Indonesian Professional Sports Agency (BOPI). Some of these cases even led to court suits. Table 1 below will explain the case of salary arrears that occurred from 2017-2019. 
Table 1 - Salary Arrears Case by League 1 and League 2 Soccer Clubs 2017-2018

\begin{tabular}{|c|c|c|c|c|}
\hline No & $\begin{array}{c}\text { Football Club } \\
\text { Name }\end{array}$ & Case & Year & Action \\
\hline 1 & $\begin{array}{l}\text { Gresik United } \\
\text { Persegres }\end{array}$ & $\begin{array}{l}\text { Arrears of player salaries in } \\
\text { League } 12017\end{array}$ & 2017 & $\begin{array}{l}\text { APPI reported the case to the Gresik } \\
\text { Manpower Office. This remedy is pursued in } \\
\text { accordance with the agreement in the player's } \\
\text { contract }\end{array}$ \\
\hline 2 & Riau PSPS & $\begin{array}{l}\text { Unpaid salaries and down } \\
\text { payments for } 12 \text { soccer players in } \\
\text { League } 22018\end{array}$ & 2018 & Lawsuit to the Riau District Court \\
\hline 3 & Sriwijaya FC & $\begin{array}{l}\text { The non-payment of the rights of } \\
28 \text { soccer players in the } 2018 \\
\text { League } 1 \text { competition }\end{array}$ & 2018 & Lawsuit against Palembang District Court \\
\hline 4 & $\begin{array}{l}\text { Persika } \\
\text { Karawang }\end{array}$ & $\begin{array}{l}\text { Arrears on the salaries of } 13 \\
\text { soccer players for } 1.5-2 \text { months in } \\
\text { the } 2018 \text { Leaque } 2 \text { competition }\end{array}$ & 2018 & $\begin{array}{l}\text { APPI sent a letter to the LIB to confirm the } \\
\text { remaining royalty payments to the club due to } \\
\text { reasons for the arrears in player salaries. }\end{array}$ \\
\hline
\end{tabular}

Source: http://www.appi-online.com/pressreleasesengketapain2018/

From the table above, it illustrates that soccer clubs in Indonesia have not yet complied with contract agreements made to players. Overall the average case for salary arrears or down payments occurs on all players in the club. The development of soccer clubs in Indonesia towards the industry has not moved since clubs were banned from using APBD funds. Football clubs in Indonesia do not have clear objectives. Often the clubs that win the first season and buy expensive and expensive players, but in the second season go bankrupt because of the debt in the first season by buying expensive star players. The management of a football club should have long-term goals, not just to become champions this season (Nugroho, GS 2017, January 9, Management Must Be 'Ball-aware', Not Just Crazy Soccer).

With an atmosphere that is far from the ideal word, the development of Indonesian football, both at the club level and the national team, is quite stagnant. However, the football industry in Indonesia still has room to grow in line with the improving economy in Indonesia. An improved economy can increase the income of sponsoring companies and encourage people's purchasing power. Football has long been a popular entertainment for all ages and groups, both in the city center and in remote villages and even soccer can be the only entertainment in an area.

With the phenomena occurring in the soccer industry in Indonesia, Bali United FC comes with an unusual breakthrough in the soccer industry in Indonesia. Bali United FC also proves to everyone that they are not just becoming an Indonesian football club that enlivens every year the Indonesian league competition revolves as is generally the case in the country, but also forms and builds this club to be more professional, both in aspects technical and non-technical. Regarding technical matters, Bali United which is classified as a 'new club' can in fact attract the attention of footballers in Indonesia and even abroad. That also made Serdadu Tridatu inhabited by many star players, both local and foreign. Not only focusing on the first team, Bali United also paid great attention to the coaching of young players so as to build academies in Bali and also East Nusa Tenggara (NTT). In this way, the club does not need to worry about running out of player resources, especially local. In fact, careful planning in this sector is often ignored by Indonesian clubs. In addition, Bali United FC is also developing business units that support the club's operations including merchandise stores, cafes \& play land, media, e-sports, and marketing agencies.

With the emergence of Bali United which changed the way of thinking and presenting something new in a football club in Indonesia into an industry that has enormous benefits for the progress of Indonesian football and the economic benefits that will also be felt for the Indonesian people and the stakeholders therein. Through the strategies adopted by Bali United, many soccer clubs in Indonesia have started to do a better club governance. Some of the strategies carried out by Bali United FC have succeeded in making large companies sponsor Bali United, such as Corsa, Cars, INA Bank, ACA Insurance, Archiles, Lion Air, and Indofood. 


\section{LITERATURE REVIEW}

According to Peteraf (Peteraf, MA, Thompson, AA, Gamble, JE, \& Strickland, AJ, 2016, Crafting and Executing Strategy: The Quest For Competitive Concepts and Cases, Vol. 20, Penn Plaza, New York, United States: McGraw -Hill Education, 3-4) company strategy is a series of actions taken by managers to outperform company competitors and achieve superior profitability. The purpose of a good strategy is not merely to achieve success and temporary competitive advantage in the short term, but on long-term sustainability that can support growth and secure the company's future in the long run. Achieving this requires making a managerial commitment to a coherent set of well-considered choices about how this competition includes choices about:

- How to attract attention and please customers;

- How can compete with rivals;

- How to position a company in the market and take advantage of exciting opportunities to develop business;

- How can respond to changes in economic and market conditions;

- How to manage each functional part of the business (R\&D, supply, chain of activities, production, sales, and marketing, distribution, finance, and human resources);

- How can I achieve the target performance of the company.

The process of making and implementing corporate strategy is an ongoing process that consists of five interrelated stages:

1) Develop a strategic vision that states the company's long-term direction, mission statement that describes the company's goals, and a set of core values to guide the pursuit of vision and mission.

2) Set goals to measure the company's performance and find out its progress in achieving the long-term direction to be achieved

3) Develop strategies to advance the company along the management pathway has mapped and achieved its performance goals

4) Implement the chosen strategy efficiently and effectively

5) Monitor developments, evaluate performance, and start corrective adjustments in the company's vision and mission, goals, strategies. or approaches to implementing strategies in the light of actual experiences, changes, conditions, new ideas, and new opportunities.

Miles and Snow (Miles, RE, \& Snow, CC (1978). Organizational Strategy, Structure, and Process. New York: McGraw-Hill) develops a comprehensive framework that discusses how organizations define and approach the market domain of their products and build structure and process to achieve competitive advantage in the domain. The framework identifies four archetypes about how companies deal with this problem. Prospectors strive to find and exploit new product and market opportunities. Defenders try to cover a portion of the total market to create a stable set of products and customers. Analyzers occupy an intermediate position by following prospectors into the new product market domain while protecting a range of products and stable customers. Reactor as the fourth type in this framework does not have a consistent response to the problem of entrepreneurship.

According to Hoye et al (Hoye, R., Smith, A., Westerbeek, H., Stewart, B., \& Nicholson, M. (2006). Sport Management Principles and Applications. Oxford, United Kingdom: Elsevier, 73-75) Strategy management is a process of achieving complementarity between preparation and opportunity. The first stage in the strategy management process is called strategy analysis. Strategy analysis covers the strengths and weaknesses of the company, competitor companies, stakeholder groups, and the business environment. After the first stage is carried out the company must determine the direction of the strategy to be used. In this stage, the company must make several decisions for the long term. For example, a mission statement displays the goals of the company, a vision statement about the long-term goals that the company wants to achieve, and sets goals with clear measurements to identify achievements related to achieving the vision. The third stage is called the development of 
strategies aimed at achieving the direction the company wants to achieve. The strategy used by the company must be in accordance with the state of the company and the state of the company's business environment. The implementation phase of the strategy related to the company's products, services, and activities is running well and the system used as a whole supports the strategy that has been developed. The last stage of strategy management is strategy evaluation. Strategy evaluation is very necessary to improve the strategies that have been used in the event of unexpected changes in the company's business environment so that it needs to go back to the first stage.

The soccer industry is different from other business industries. The uniqueness of the football industry is the phenomenon of people acting irrationally in supporting their proud clubs. Football is a symbol of the relationship between performance results, success, and celebrating achievements that are not possessed by economic areas and other social activities. People act irrationally in terms of buying match tickets, being a club supporter, donating time to the club, or buying club merchandise (Hoye, R., Smith, A., Westerbeek, H., Stewart, B., \& Nicholson, M. (2006) Sport Management Principles and Applications Oxford, United Kingdom: Elsevier, 4).

Funding for football clubs was initially like conventional organizations, namely the government imposed capital restrictions in it. Club funding is measured using the success of a team, the more successful a team is evidenced by the degree achieved the more revenue generated from ticket revenue. According to Flotnes football club (Flotnes, TG (2011). Factors of success for Norwegian top football clubs. Thesis. MSc Applied Economics and Finance. Copenhagen Business School) has several sources of income, namely as follows:

a) Income from matches (match day) is revenue derived from ticket sales and other facilities such as food and beverages;

b) Income from sponsors and advertisements is income derived from the inclusion of sponsor brand logos on player jersey, sponsor brand logos in stadiums and advertisements related to matches which are broadcast on television;

c) Income from television and media is income derived from broadcasting rights over matches aired on television; players.

d) Income from player contracts is revenue derived from the sale and purchase of

The word "strategy" comes from the Greek word "strategy" which means "planning the annihilation of the enemy through the effective use of resources" (Azhar Arsyad, 2002, Learning Media, edition 1, Jakarta, 78). The term strategy was used in the military field. Meanwhile, according to Watson strategy is what is compiled by a coach before a big game (Watson).

David defines strategy as a tool to achieve long-term goals, is a potential action that requires top-level management decisions and resources of the company / organization in large numbers. In addition, it was also emphasized that the strategy could affect the prosperity of the company / organization in the long term and future-oriented. Strategy has multifunctional and multidimensional consequences and needs to consider external and internal factors faced by the company / organization (David Fred R, 2006, Strategy Management, 45-47).

While Pearce and Robin interpret the strategy is a large-scale plan, with a future orientation, in order to interact with competitive conditions to achieve corporate / organizational goals (John A. Pearce II and Richard B. Robinson Jr., 2008, Strategic Management Formulation, Implementation and Control, Jakarta, 34-37). Strategy is a matter of setting direction to management in terms of people about the resources in the business and about how to identify the conditions that provide the best benefits to help win the competition in the market. In other words, the definition of strategy contains two components, namely; future intentions (long-term goals) and competitive advantage or competitive advantage (Crown Dirgantoro, 2001). Both of these are a final combination to be achieved by the company and how to achieve these final goals.

Strategy is a comprehensive plan that integrates resources and capabilities with a longterm goal to win the competition (Tjutju Yuniarsih and Suwanto, 2011). Strategy in the 
business world is defined as a plan method, or series of activities designed a particular educational goal, which means that the strategy is a plan that contains a series of activities designed to achieve certain business goals (Wina Sanjaya, 2006). According to Watson strategy is the firmness of a vision. Strategy is the ability to see the direction to be headed, and to do the things needed to stay on the path to achieving that goal (Watson).

Strategy is a broad program to achieve organizational goals, meaning how to carry out its mission. The word "program" in this definition reflects the active, conscious and rational role played by managers in formulating organizational strategies. A strategy establishes an integrated direction from its various objectives, and guides the use of the resources needed to move the organization towards that goal (Rustam Effendy). Strategy can also be interpreted as a pattern of organizational responses to their environment in a period of time. The strategy of connecting people and other resources in an organization on the one hand with challenges and risks those come from the outside world on the other (Rustam Effendy).

\section{METHODS OF RESEARCH}

In this study the authors used a qualitative descriptive study because this study explored the phenomenon of business strategy in the environment of soccer clubs in Indonesia. The use of the case study research approach is expected to be able to answer questions regarding the business strategy of the football club implemented at Bali United FC. The research was conducted at PT Bali Bintang Sejahtera (Bali United FC) located on Jalan Pararaton 2, Legian Village, Kuta District, Badung Regency, Bali Province. The selection of Bali United FC as an object of research is because Bali United FC is a football club that has merchandise stores, websites, applications, TV clubs, Bali United Café, Bali United Land and professionally managed social media, Bali United FC has many sponsors, Bali United FC has long-term contracts with young players and stadiums, Bali United has a number of corporate social responsibility programs including club social actions, million - ball movements, free coaching clinics, going to school, having supporters with high loyalty.

Data collection techniques used in this study are Observation of data collection by observing people or events in the work environment and recording the information obtained (Sekaran \& Bougie 2013). This research will observe the condition of Bali United FC directly, the activities of Bali United FC and also each individual involved in these activities. And also the interview method is a method of collecting data that researchers and participants in a conversation that aims to obtain information related to the research conducted (Sekaran \& Bougie 2013). Interviews were conducted to obtain information about the business strategies carried out at Bali United FC. The interview technique used was semi-structured to parties related to the business strategy carried out, including the chief commissioner, chief director, marketing director of PT Bali Bintang Sejahtera (Bali United FC). Documentation by obtaining research data can also be made from documents that are already available.

\section{RESULTS AND DISCUSSION}

The company strategy used by PT Bali Bintang Sejahtera (Bali United FC) itself in this case is a location that he thinks Bali has a very attractive brand or brand because of its good community culture, kinship. The Attraction of Bali is the beginning of the business strategy used by Bali United FC. In this case Bali United FC found opportunities for new products or markets (prospectors). Bali United FC chose location as the initial business strategy, according to him the chosen location was an initial opportunity in business management itself. Where there will be sponsors and supporters who will complement each other. According to the interview results, the sponsor will issue the product that the fans will use, while what the fans want is an achievement, it is an analysis of the strategy used by Bali United FC in the business environment. The implementation of this strategy creates a deeper meaning, not only encouraging existing supporters to return to making purchases, but also attracting new supporters through achievements that will be enhanced by the football club itself. Bali United FC itself has listed various sponsors who support the progress of Bali 
United FC. Big sponsors have been sponsors of Bali United FC for the past few years. Sponsors of Bali United FC include Indofood, Indomie, Achilles, Corsa, Smartfren, Bank INA, Torabika, Cars, Elevenia, ACA, Aishaderm, Sari Roti, Gojek, Kukubima, Envi, Lion Parcel, Cellular World, Cocomart, Bareksa, Syailendra, Buana Capital, Bebek Bengil, YCAB, and Kick Andy.

Some of the innovations that have been made by Bali United to make a competitive advantage are to make a football club more than a sport, but rather a brand. In this stage, Bali United FC targets to be able to influence positive things for the fanatical fans of Bali United to make Bali United not just a football club but a brand to be proud of. The strategic planning step undertaken by Bali United FC to make Bali United a trademark is to make Bali United Stadium and other major business activities a must-visit destination in Bali, create the most entertaining stadium experience in Indonesia, create and optimize Bali United channels through digital media such as applications and digital radio and established a football foundation with the best facilities in Indonesia. With fanatical fans, Bali United believes it can influence the market mainly through retail products. Steps taken by Bali United FC include influencing existing communities, and increasing sales of partners / sponsors through channels owned by Bali United FC.

The real proof of the development of the Bali United FC strategy is that Bali United is a pioneer of social media content for the soccer team in Indonesia with a global community of 1.5 million. The steps taken by Bali United FC to achieve the basic strategy of acquiring fans are to become champions of football clubs in Indonesia, become trendsetters and influencers throughout Asia, become soccer clubs with leading innovations in business, marketing \& technology, gain new potential fans by forming " talent management "new division so that content players / Bali United FC can be well managed and expand the Bali United FC community into other categories such as music, food, art, and the esports community. In addition, Bali United FC will focus more on the millennial market. One of the business strategies that Bali United FC management carries out is to meet the needs of fans and also add to the team's financial revenue including Bali United Merchandise Store, Bali United Café, Bali United Playland, Bali United Academy, Bali United Media, e-Sports, Marketing Agency, Bali United FC Product and Service Development

Benchmarking strategies used by Bali United FC itself by imitating foreign clubs, then comparing and making new breakthroughs for Bali United's own club. Wherein the results of interviews from the three informants said the same thing, which was to use a copycat observing strategy, one of the strategies used was one of learning from Manchester United, because their sponsors and supporters were already around the world. They even have a fan director, because they are global. The number of their fans is global. And maybe we will try it in Bali, so that it can align with the activities of sponsors and supporters. Increasing their problems. The reason why choosing it is because it is a successful strategy, because between the club, sponsors and supporters all work together.

From the results of interviews with the three informants, the business strategy used by the management of Bali United FC is to use a benchmarking method, where they mimic foreign clubs Manchester United. They imitate Machester United by forming a Technical Team and Business Team. The business team in this case are people who are experienced or professional in marketing to find sponsors and income to fund the technical team. The technical team in this case is the coach and the player. So if the business team is able to get the maximum income, the performance of the technical team is increasing because they are able to get quality coaches and players, adequate facilities, and can meet the needs of the technical team. So if a club achieves the best performance, more fans will support it and it will be increasingly known throughout Indonesia and all over the world, so even if the competition doesn't run, management will still be able to earn from some of the branding they have built, because they can optimize the name big from these ball clubs.

Reciprocal relationships are often referred to as interrelationship, where the relationship between two variables that influence each other. One example of reciprocal correlation in this case is the relationship between management and sponsors. Reciprocal relationship in this case according to Informant: Mr. Peter Tanuri: "We are talking about 
business, whoever we make a good partner of TV merch ticket sponsors, they must have 2 impacts, 1 brand awareness that has an increasing brand. Both sales went up. If they sell up they are certainly fast. So my strategy is how every person we invite sales cooperation to go up, the name is famous. It also depends on how our assets are players and don't forget the fans. Fans know not if they support a club he must also defend the product of helping from the team itself. Players also help promote and fans must know this is the company that helps their team. That's the education that we do. The factors that most influence: 1 . From the team itself there must be achievements, both in terms of management, the industry must be able to sell achievements or when underachieving". According to the Informant Mr. Yabes Tanuri: "From there we can profit, and the client is divided into 2, sponsors and supporters. 1 sponsor is how the product is used by supporters, if supporters how do we provide achievements and facilities that we try to improve continuously. The increased sponsors make money, the achievement results in costs because the better the players the higher the costs. They have another fan director, because they are global. The number of their fans is global. And maybe we will try it in Bali, so that it can align with the activities of sponsors and supporters. Increasing their sales. The reason why choosing it was because it was a successful strategy, because between the club sponsors and supporters synergized. The most influential if until now, we have different sponsors from other clubs, because we consider sponsors and supporters as clients. How do we get money from sponsors and how can we excel through sponsors and supporters, basically all must synergize. There are no supporters, the sponsors don't want to. But if we don't spend money on achievements, there are no supporters. Supporters' groups are different, there are groups who want to be invited by sponsors or not, so we must explain that the income from sponsors is $80 \%$, once it's gone I can just walk but the players are cheap and no strangers. So we must be able to subtly tell supporters that this is a business, because big clubs like MU and PSG are looking for sponsors abroad but we can't yet, and it is proven, for example MU archiles support, sales in Asia and Indonesia go up because many MU fans. But when it is also tried locally, for example, Persib, even more sales also increase $100 \%$ more, it turns out that the fanaticism of local clubs is greater than outside. According to Ms. Katharine: "Almost everything has an effect, from the team's fans and management". Synergy number 1 from all sides must understand each other. Management is divided into technical and business teams. The business team must be smart in finding revenue so that they can buy and pay players and complete technical needs, and the technical team must also be aware that if there are no sponsors, they cannot get a salary. But the time has to be divided, when the technical team exercises and when they have to fill their business time and when they are performing. Fans also need to be aware and know their rule must support sponsors because without team sponsors there will be no income.

Based on interviews from the three informants, reciprocity in this case between the club, sponsors and supporters. The club must produce the best players and excel, the more players perform, the more supporters will be and the club will become more global, this is proven by the achievements carved by Bali United FC in 2019, this club won the League 1 soccer match in Indonesia and defeated several other football clubs, and now Bali United is advancing in the Asian League, this has made the name of Bali United itself increasingly global and there will be more and more fans from the Bali United club because it carves good achievements. The more supporters and the more well-known Bali United will bring sponsors, the sponsors who fund Bali United will become famous, because the sponsor's brand will surely appear when Bali United is competing against which funds from the sponsor's brand will rise. This also affects the Club from Bali United, the more sponsors the better the quality of the players, because players get salaries from sponsors and the club also benefits from ticket sales that fans buy. So the interrelationships of the three are mutually sustainable, mutually influencing each other, there are no sponsors and supporters so there is no income to the club, then there is no good and quality players because of the lack of costs to facilitate players, the absence of good players, the club does not will achieve and the name will sink, the more qualified the player, the more supporter will be and will be 
more and more happy to eat sponsors, and the brand of sponsors will be more famous and sales will increase.

\section{CONCLUSION AND SUGGESTIONS}

The strategy that the management of Bali United FC uses in running their business is the Benchmarking or ATM (Strategy to Observe, Modify and Modify) strategy, one of the clubs they emulate is Manchester United's foreign club, which is from the way it is managed, even though the club is not the champion but merchandise sales are very good and the presence of fans in each match remained stable. For the management of the club Bali United FC, every sponsor who collaborates with them always strives that the brand will become more famous and increase sales. Because in addition to the fans the club players of Bali United FC also helped promote the brand of the sponsors. The factor of the team also influences the sponsors, because the team must excel so that more fans use and buy products from sponsors and merchandise from the club Bali United FC. So that the management of Bali United FC formed a Business and Technical Division Team, in terms of the business team working for the financial income of the team in order to meet all operational needs needed by the technical team in improving the performance of players so that they can provide the best. With the improvement in the quality of players, this will facilitate their achievement. Then fans or supporters will increase and support by buying merchandise from the club Bali United FC, and this will attract other companies to sponsor Bali United FC.

The implementation of the Bali United FC business strategy is by choosing a strategic location, that is in Bali, and after being run by the community and the government is very supportive of the existence of Bali United FC, it can be seen from the government support that is providing stadium leases with its management owner Bali United FC management for 20 years since 2015. Benchmarking strategy after being implemented at Bali United FC is going well, it has proven that sales are increasing, sponsors are increasing and the team is achieving more.

Suggestions given by researchers to the Bali United FC, the researchers hope that the business management team is based in Bali, to facilitate the management of the Bali United FC club system. So that the performance of the business management of Bali United Fc is getting maximum, because it is known that the center of business management is in Jakarta.

The second suggestion is that the management of Bali United FC can overcome the difficulty of fans getting tickets during the big match and find out audience loyalty by making channel tickets so that fans don't only come during big match matches.

This research is expected to be able to increase the knowledge and insight of the compilers about the importance of the benefits of business strategy practices that actually occur in football clubs in Indonesia, besides it is expected to be a reference for other researchers who conduct research with the same object so as to develop knowledge in management strategy. And can be a reference material and consideration for PT Bali Bintang Sejahtera (Bali United FC) in improving the implementation of existing business strategies and improving the implementation of business strategies that do not yet exist so that later will provide a reference in evaluating the implementation of the company's business strategy.

\section{REFERENCES}

1. Andrew, R., \& Suryawan, I. N. (2015). Studi Literasi Pengembangan Manajemen Klub Sepak Bola di Indonesia. MODUS Vol.27 (2), 175-182.

2. Barley, S., \& Tolbert, P. (1997). Institutionalization and Structuration: Studying the Links between Action and Institution. Organization Studies, 18, 93-117.

3. Berthod, O. (2016). Institutional Theory of Organizations. Springer International Publishing AG, 1-5. 
4. Callejo, M. B. (2006). Real Madrid Football Club: A New Model of Business Organization for Sports Clubs in Spain. Global Business and Organizational Excellence, 51-64.

5. CGR, G. R. (2014). GAMA RISPRO CGR Pemeringkat Tata Kelola (Governansi) Korporat Independen. Retrieved from http://gamacgr.org/: http://gamacgr.org/

6. Creswell, J. W. (2014). Research Design: Qualitative, Quantitative and Mixed Method Approachesn 4th Edition. United States of America: SAGE Publications.

7. Dolles, H. (2005). Globalization of Sports - The Case of Professional Football and its International Management Challenges. German Institute for Japanese Studies.

8. Flotnes, T. G. (2011). Factors of success for Norwegian top football clubs. Thesis. M.Sc Applied Economics and Finance. Copenhagen Business School.

9. Freeman, R Edward, Harrison, J. S., Wicks, A. C., Parmar, B. L., \& Colle, S. D. (2010). Stakeholder Theory The State of The Art. United Kingdom: Cambridge University Press.

10. Hoye, R., Smith, A., Westerbeek, H., Stewart, B., \& Nicholson, M. (2006). Sport Management Principles and Applications. Oxford, United Kingdom: Elsevier.

11. Kartakoullis, N. L. et al (2013). Strategic resource planning for football clubs. J. International Business and Entrepreneurship Development, Vol. 7, No. 1, 1-20.

12. Kresna Sekuritas, \& Buana Capital. (2019). Prospektus Awal Penawaran Umum Perdana Saham PT Bali Bintang Sejahtera Tbk. Jakarta: Kresna Sekuritas \& Buana Capital.

13. Marquez, M., \& Martin, H. (2000). The New Football Business: a challenge for elite followers. A Case Study for Ifk Göteborg. International Business. Master Thesis.School of Economics and Commercial Law. Göteborg University.

14. McNamara, P., Peck, S. I., \& Sasson, A. (2013). Competing Business Models, Value Creation and Appropriation in English. Long Range Planning 46, 475-487.

15. Miles, R. E. (1978). Organizational Strategy, Structure, and Process. NY: McGraw-Hill.

16. Narazine. (2016, November 28). Industri Sepakbola Nasional Antara Impian dan Ironi. Retrieved from http://narazine.co/industri-sepakbola-nasional-antara-impian-dan-ironi/

17. Nugroho, G. S. (2017, Januari 9). Manajemen Harus 'Sadar Bola', Bukan Cuma Gila Bola. Retrieved from http://gantigol.com/

18. Nurdiyanto, A. (2018). Strategi Integrated Marketing Communication Dalam Mendapatkan Sponsorship Klub Sepak Bola (Studi Deskriptif Kualitatif Pada Persebaya Surabaya FC Kompetisi 2017). Skripsi. Universitas Islam Negeri Sunan Ampel Surabaya.

19. Olson, E. M., Duray, R., Cooper, C., \& Olson, K. M. (2016). Strategy, Structure, and Culture within the English Premier League (An examination of large clubs). Sport, Business and Management: An International Journal Vol. 6 No. 1, 55-75.

20. Peteraf, M. A., Thompson, A. A., Gamble, J. E., \& Strickland, A. J. (2016). Crafting and Executing Strategy:The Quest For Competitive Concepts and Cases (Vol. 20). Penn Plaza, New York, United States: McGraw-Hill Education.

21. PSSI. (2014). Regulasi PSSI tentang Status dan Transfer Pemain. Persatuan Sepakbola Seluruh Indonesia.

22. Republik Indonesia. (2005). Undang-Undang Republik Indonesia Nomor 3 Tahun 2005 Tentang Sistem Keolahragaan Nasional.

23. Rikardsson, H., \& Rikardsson, L. (2013). Strategic Management in Football (How the European top club could adjust to UEFA financial fair play and simultaneously create conditions for competitive advantage within the changing UEFA football industry). Master Thesis in Business Administration International Business and Economics Programme Advanced level, 30 credits Spring semester.

24. Rowbottom, N. (1998). Intangible Asset Accounting and Accounting Policy Selection in The Football Industry. Thesis, Faculty of Commerce and Social Science, Department of Accounting and Finance School of Business, the University of Birmingham.

25. Sekaran, U., \& Bougie, R. (2013). Research Method for Business (Sixth Edition). United Kingdom: Wiley \& Sons Ltd.

26. Senaux, B. (2008). A Stakeholder Approach to Football Club Governance. Int. J. Sport Management and Marketing, Vol. 4, Nos. 1/2,, 4-17.

27. Sener, I., \& Karapolatgil, A. A. (2015). Rules of the Game: Strategy in Football Industry. Procedia - Social and Behavioral Sciences 207, 10-19. 